EDITORIAL

\title{
KIDNEY DISEASES IN CHILDREN - EARLY DIAGNOSIS AND PREVENTION
}

\author{
Momir Polenakovic', Zoran Gucev², Velibor Tasic ${ }^{2}$ \\ ${ }^{1}$ Macedonian Academy of Sciences and Arts, Skopje, R. Macedonia \\ ${ }^{2}$ University Children's Hospital Medical School, Skopje, R. Macedonia
}

Corresponding Author: Prof. Momir Polenakovic, MD, PhD, Macedonia Academy of Sciences and Arts, Bul. Krste Misirkov, No. 2, 1000 Skopje, Republic of Macedonia; E-mail maknefpo@t-home.mk

\begin{abstract}
Pediatric kidney diseases were in the focus of the World Kidney Day 2016. Macedonian pediatric nephrologists gave their contribution with public appearance in kindergartens, primary and seconddary schools, with interactive lectures and discussion with the youngest about the kidney function, healthy life style and simple measures to prevent kidney and urinary tract diseases. Besides promotive appearance in the media, series of lectures were presented in front of the health professionals. The aim was to attract the attention of the professionals for early diagnosis and prevention of kidney disease. The action starts in utero, followed by early postnatal imaging and assessment, conservative treatment and in selected cases surgical treatment. The emphasis is on the multidisciplinary and comprehensive approach to children and adolescents with kidney diseases.
\end{abstract}

Keywords: World Kidney Day, pediatric kidney diseases, prevention

The 11th World Kidney Day was celebrated on March 10, 2016, around the globe. This event was sponsored in the Republic of Macedonia by the non-governmental renal patient organization (Nephron) and the Macedonian Societyfor Nephrology Dialysis Transplantation and Artificial Organs (MSNDTAO). There are about 1.400 patients on chronic dialysis program in the Republic of Macedonia. The number of transplants is limited and is mainly confined to living kidney transplantation. Due to the limited resources it is mandatory to promote preventive measures for early diagnosis, appropriate treatment and prevention of chronic kidney diseases.

In 2016, the World Kidney Day was dedicated to the kidney disease in childhood and the antecedents of adult kidney disease, which can begin in the earliest childhood [1]. Macedonian pediatric nephrologists gave their contribution with public appearance in kindergartens, primary and secondary schools with inte- ractive lectures and discussion with the youngest about the kidney function, healthy life style and simple measures to prevent kidney and urinary tract diseases. The aim was to attract the attention of the youngest to the kidneys as very important organ for elimination of the waste. The youngest had their exhibition of the paintings with very imaginative presentation of the kidneys (Figures 1 and 2).

Besides the promotive appearance in the media a series of lectures were presented in front of the health professionals. The aim was to attract the attention of the professionals for early diagnosis and prevention of kidney disease. The action starts in utero, followed by early postnatal imaging and assessment, conservative treatment and in selected cases surgical treatment. Macedonian nephrologists presented their data on the spectrum of kidney disease, and pointed that congenital anomalies of the kidney and the urinary tract (CAKUT) are still the leading etiology of the chronic kidney disease (CKD). 
The emphasis was on the comprehensive evaluation of the patients, particularly in the case of syndromic cases. Although there is still a high genetic heterogeneity in children with CAKUT the molecular diagnosis is possible. Hyperechogenic and dysplastic kidneys seen on the prenatal ultrasound are often the result of mutation of $H N F 1 B$ gene [2]. Besides nephropathy these

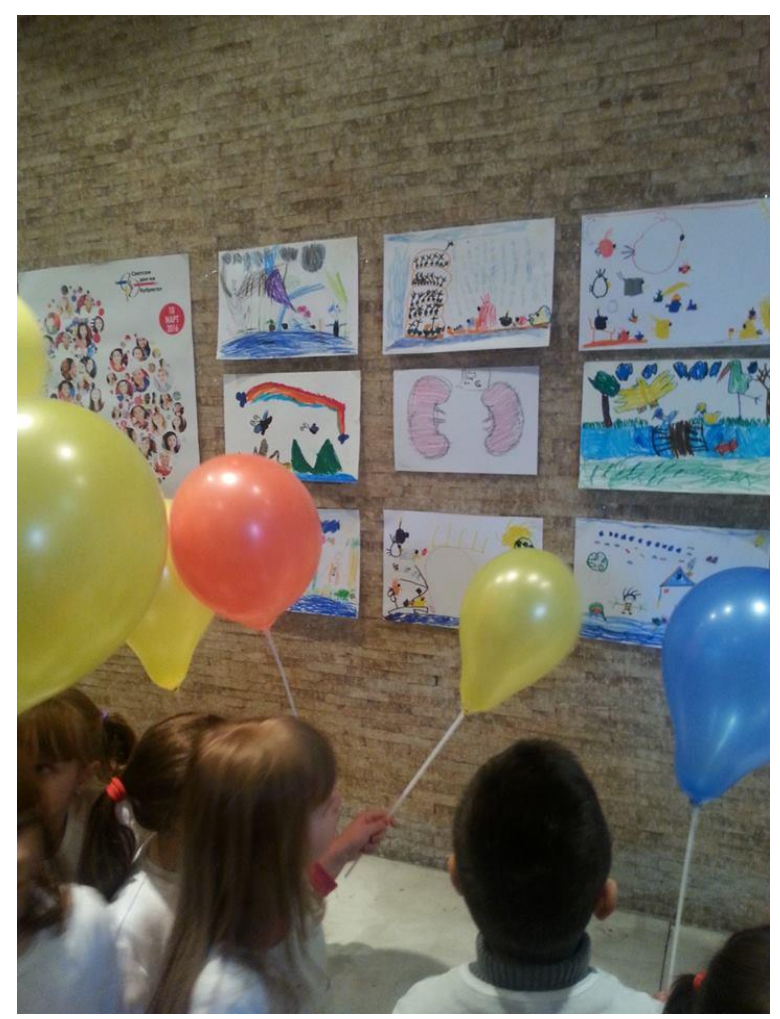

Fig. 1 -Children participants in the World Kidney Day 2016

In the presented lectures particular attention was paid to the progression of the chronic kidney diseases in children. The standard factors which may affect progression of CKD in adults are hypertension, proteinuria, glomerular etiology, male gender, anemia, diabetes, dyslipidemia, hyperparathyroidism, malnutrition (hypoalbuminemia) which also operate in children.

The focus of researchers in the last two decades is concentrated on the abnormal birth history [prematurity, low birth weight (LBW), or small for gestational age (SGA)] which are associated with hypertension, chronic kidney disease, cardiovascular morbidity, obesity and diabetes mellitus in adulthood [4]. Low birth parameters are factor for initiation of CKD, but not significant factor for progression to ESRD as it was shown in a large Japanese pediatric study [5]. patients may develop later in life MODY5 diabetes, hypomagnesemia, hyperuricemia and gout and gynecological problems due to associated urogenital anomalies. Children with mutation in EYA1, SIX1, SIX5 mutation clinically present as a BOR syndrome; besides CAKUT, a serious problem is the associated hearing impairment [3].

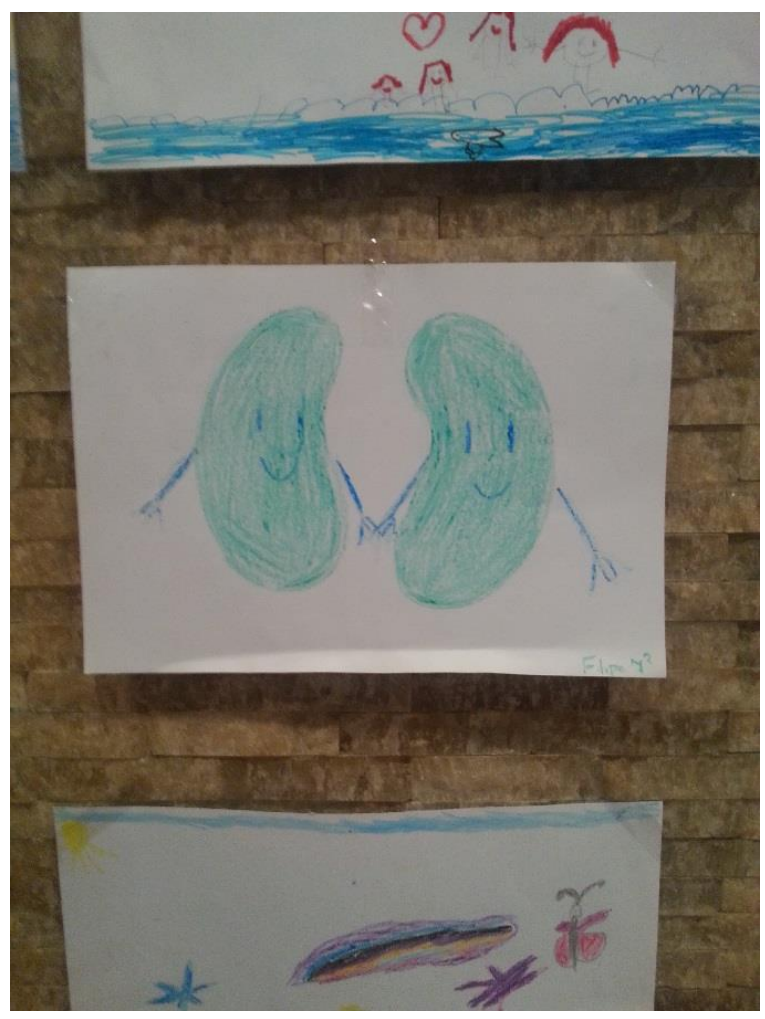

Fig. 2 -Children's paintings at the World Kidney Day 2016

The other important pediatric risk factor is obesity. There is a global, worldwide epidemic of obesity affecting not only adults but particularly children and adolescents. The sedentary style of life, consumption of junk food, lack of physical activity contributed to the magnitude of this epidemic. There is a clear evidence that obesity is an independent risk factor for progression of CKD as in the case of IgA nephropathy, patients with unilateral renal agenesis or nephrectomy [6]. Even renal allograft dysfunction was noted with higher rate in kidneys from obese donors compared to lean donors' kidneys.

Smoking is another important but underrated risk factor in renal patients. The increasing prevalence of smoking among adolescents has negative impact on the renal functions. The adult studies clearly demonstrated unfavorable effect of tobacco use in patients with IgA neph- 
ropathy, diabetic nephropathy and allograft nephropathy. Besides nicotine there are $>4000$ toxic chemicals including carbon monoxide, arsenic, vinyl chloride, cadmium, lead, and acrolein, which have negative impact on the kidney function [7].

Instead of conclusion, the global message from the World Kidney Day 2016 in the Republic of Macedonia is early and effective diagnosis of kidney disease, preventive measures which include improving the pre-, peri-, and post-natal health care and struggle against prematurity, obesity and smoking. Health professsionals should be the principal promotors of this action, but the role of society is of utmost importance in education and promotion of the healthy life style.

\section{REFERENCES}

1. Ingelfinger JR, Kalantar-Zadeh K, Schaefer F. World Kidney Day Steering Committee. Averting the legacy of kidney disease-focus on childhood. Kidney Int. 2016; 89: 512-8.

2. Bockenhauer D, Jaureguiberry G. HNF1B-associated clinical phenotypes: the kidney and beyond. Pediatr Nephrol. 2016; 31: 707-14.

3. Song MH, Kwon TJ, Kim HR, Jeon JH, Baek JI, Lee WS, et al. Mutational analysis of EYA1, SIX1 and SIX5 genes and strategies for management of hearing loss in patients with BOR/BO syndrome. PLoS One. 2013; 8(6): e67236.

4. Franke D, Völker S, Haase S, Pavicic L, Querfeld U, Ehrich JH, Zivicnjak M. Prematurity, small for gestational age and perinatal parameters in children with congenital, hereditary and acquired chronic kidney disease. Nephrol Dial Transplant. 2010; 25: 3918-24.

5. Ishikura K, Uemura O, Hamasaki Y, Ito S, Wada N, Hattori M, et al. Pediatric CKD Study Group in Japan; Committee of Measures for Pediatric CKD of Japanese Society of Pediatric Nephrology. Progression to end-stage kidney disease in Japanese children with chronic kidney disease: results of a nationwide prospective cohort study. Nephrol Dial Transplant. 2014; 29: 878-84.
6. Ding W, Cheung WW, Mak RH. Impact of obesity on kidney function and blood pressure in children. World J Nephrol. 2015; 4: 223-9

7. Omoloja A, Tyc VL. Tobacco and the pediatric chronic kidney disease population. Pediatr Nephrol. 2015; 30: $235-43$.

Резиме

\section{БУБРЕЖНИ ЗАБОЛУВАЊА КАЈ ДЕЦАТА - РАНА ДИЈАГНОЗА И ПРЕВЕНЦИЈА}

\section{Момир Поленаковиќ ${ }^{1}$, Зоран Гучев ${ }^{2}$, Велибор Тасиќ ${ }^{2}$}

${ }^{1}$ Македонска академија на науките и уметностите, Скопје, Р. Македонија, 2 Универзитетска клиника за детски болести, Медицински факултет, Скопје, Р. Македонија

Педијатриските бубрежни заболувања беа во фокусот на Светскиот ден на бубрегот 2016 година. Македонските педијатри нефролози дадоа свој придонес со посети на градинки, на основни и на средни училишта и со интерактивни предавања дискутираа со најмладите за функцијата на бубрезите, за здравиот начин на живеење и едноставните мерки за спречување заболувања на бубрезите и на уринарниот тракт. Покрај промотивна појава на медиумите, тие презентираа серија предавања за здравствените професионалци. Нивна цел беше да се привлече вниманието на професионалците за рана дијагноза и превенција на бубрежните заболувања. Акцијата започнува уште in utero проследено со ран постнатален imaging и процена, конзервативен третман, а во селектирани случаи и хируршки третман. Акцентот е ставен на мултидисциплинарниот и сеопфатен пристап кон децата и адолесцентите со бубрежни заболувања.

Клучни зборови: Светски ден на бубрегот, педијатриски бубрежни заболувања, превенција 